\title{
ІСТОРИКО-ТЕОРЕТИЧНІ ЗАСАДИ РОЗВИТКУ ПРОФЕСІОНАЛІЗМУ ВИХОВАТЕЛІВ ЗАКЛАДІВ ДОШКІЛЬНОЇ ОСВІТИ
}

\author{
Самсонова О. 0. \\ кандидат педагогічних наук, \\ доиент кафедри дошкільної та початкової освіти \\ Запорізький національний університет \\ вул. Жуковського, 66, Запоріжжя, Украӥна \\ orcid.org/0000-0001-6213-9276 \\ golovinova.189@gmail.com
}

\begin{abstract}
Ключові слова:
історико-теоретичні засади, розвиток професіоналізму, вихователь закладу дошкільної освіти, дитиноценризм, дошкільна освіта, професія.
\end{abstract}

У статті висвітлено філософські, педагогічні, психологічні підходи до розуміння розвитку дошкільної освіти як початкової ланки всісї освітньої системи. Визначено пріоритети дошкільної освіти, розглянуто підходи до розвитку професіоналізму вихователя закладу дошкільної освіти. Проаналізовано надбання педагогічної та психологічної теорії щодо становлення й розвитку дошкільної освіти, історико-теоретичні засади процесу розвитку професіоналізму вихователів закладів дошкільної освіти, визначено його хронологічні періоди та їх характеристики. Так, на основі критеріальної матриці визначено такі етапи: загальнотеоретичний (до середини 80-х рр. ХХ ст.), у якому відбувалося формування теоретичної основи дошкільної освіти, а також програмно-методичне оформлення його змісту; парадигмальний (1986-1991рp.), у якому запропоновано базові концепції дошкільної освіти, що визначили принципово нові підходи до ії змісту; концептуальний (1992-1999 рр.), у якому розроблено та представлено варіативні психолого-педагогічні концепції дошкільної освіти. Також розкрито проблему сучасного закладу дошкільної освіти, який гостро потребує вихователя, здатного адекватно і швидко реагувати на зміни освітньої ситуації, використовувати інноваційні технології виховання, спроможного до принципової їх переорієнтації на сучасні пріоритети, до творчого розв'язання нових назрілих проблем, у зв'язку 3 чим мета освіти може бути представлена як безперервний особистіснопрофесійний розвиток педагога якісно нового типу. Звертається увага, що наукою доведено таке: закономірності творення нової особистості в умовах сьогодення як ніколи актуалізують проблему розвитку професіоналізму фахівця в сучасній теорії та практиці навчання й виховання, а формування й удосконалення компонентів досліджуваного феномена можливі тільки в процесі саморозвитку особистості. 


\title{
HISTORICAL-THEORETICAL PRINCIPLES OF DEVELOPMENT OF PROFESSIONALISM OF PRE-EDUCATION EDUCATORS
}

\author{
Samsonova O. O. \\ PhD in Pedagogy, \\ Associate Professor at the Department of Preschool and Primary Education \\ Zaporizhzhia National University \\ Zhukovskoho str., 66, Zaporizhzhia, Ukraine \\ orcid.org/0000-0001-6213-9276 \\ golovinova.189@gmail.com
}

Key words:

historical and theoretical foundations, professionalism development, teacher of preschool education institution, child-centeredness, preschool education, profession.

\begin{abstract}
The article covers philosophical, pedagogical and psychological approaches to understanding the development of preschool education as the starting point of the whole educational system. The main priorities of preschool education are identified, approaches to the development of professionalism of a preschool teacher are considered. The achievements of pedagogical and psychological theory concerning the formation and development of preschool education, historical and theoretical foundations of the process of professional development of preschool teachers, their chronological periods, and their characteristics are analyzed. Thus, the following steps are defined on the basis of the criterion matrix: general theoretical (up to the middle of the 80-ies of the twentieth century.), in which the theoretical basis of preschool education was formed, as well as the programmatic and methodological design of its contents; paradigmatic (1986-91), which outlines basic concepts of early childhood education that have identified fundamentally new approaches to its content; conceptual (1992-99), which developed and presented the variant psycho-pedagogical concepts of preschool education. Also, the article reveals the problem of a modern preschool education institution, which desperately needs an educator who is able to respond adequately and quickly to changes in the educational situation, to use innovative education technologies, capable of principally reorienting them to modern priorities, to creatively solving new emerging problems, The purpose of education can be represented as continuous personal and professional development of a teacher of a qualitatively new type. Attention is paid to the fact that science has proved that the laws of creation of a new personality in the present-day conditions never more actualize the problem of professional development of a specialist in the modern theory and practice of teaching and training, and the formation and improvement of components of the phenomenon under study is possible only in the process of personality development.
\end{abstract}

Постановка проблеми. Дослідження проблеми розвитку професіоналізму вихователів закладів дошкільної освіти потребує об'єктивного й різнопланового вивчення педагогічних тенденцій сучасної освіти, визначення історико-теоретичних засад. Це сприятиме глибшому розумінню проблеми та іiї оцінюванню з погляду сучасних освітніх тенденцій. Кожна з виділених тенденцій уже була предметом прискіпливої уваги українських і зарубіжних учених, однак у контексті обраної проблематики все ж потребує певної деталізації та уточнення.

Аналіз останніх досліджень i публікацій. Проблема професійної діяльності педагога дошкільного профілю загалом і розвитку профе- сіоналізму зокрема вивчена в теорії та методиці професійної освіти значно менше, хоча їй приділяли увагу в працях такі психологи й педагоги, як Ш. Амонашвілі, Л. Артемова, А. Богуш, Д. Ельконін, С. Козлова, В. Логінова, Т. Поніманська, Н. Щелованов та інші. Виявлено, що їй притаманні всі риси педагогічної діяльності, але вони набувають особливого забарвлення в діяльності педагога, який здійснює навчання й виховання дітей раннього та дошкільного віку. Фундаментальна роль дошкільного періоду розвитку в процесі становлення особистості визначає відповідні вимоги до вихователя, передусім це необхідність усвідомлення найвищої відповідальності за щасливе дитинство дитини та їі долю [5, с. 19]. 
Суттєвий інтерес для дослідження становлять праці, у яких висвітлено положення акмеології про особистісно-професійний розвиток (Б. Ананьєв, О. Бодальов, А. Деркач, В. Зазикін, В. Максимова, А. Реан та інші); особливості професійної підготовки майбутніх вихователів дошкільних навчальних закладів (В. Бенера, Ю. Волинець, Н. Давкуш, С. Зонтова, Л. Кідіна, Л. Козак, Р. Кондратенко, О. Кучерявий, Х. Шапаренко, І. Шевченко, О. Шовкопляс); управління інноваційними процесами в дошкільних навчальних закладах (О. Зайченко, Т. Махиня, С. Пєхарева, О. Янко); управління навчально-виховним процесом у дошкільних навчальних закладах (О. Багінська, Н. Воловик, Л. Врочинська, С. Гаврилюк, Н. Голота, Н. Лазарович, Г. Скірко); проблеми професійного розвитку та формування професійної компетентності вихователів дошкільних навчальних закладів (Г. Бєлєнька, Н. Маковецька); розвиток професійної компетентності педагогів дошкільних навчальних закладів у системі післядипломної освіти (Н. Давидюк, О. Томей); створення іміджу дошкільного закладу й вихователів ДНЗ (М. Апраксіна, К. Крутій, Р. Шулигіна).

Дослідження цих та інших авторів підтверджують думку, що ключове поняття професіоналізм є складним і полівекторним. Так, І. Зязюн підкреслював, що, крім знань і вмінь, педагогові необхідні певні особистісні якості, адже саме він $€$ інструментом впливу на взаємодію 3 дітьми, батьками, колегами. Цей інструмент - його душа - має бути чутливим до іншої людини, гуманним у своїх помислах [4, с. 5].

Мета статті - 3'ясувати історико-теоретичні засади розвитку прфесіоналізму вихователів закладів дошкільної освіти й визначити його хронологічні періоди.

Виклад основного матеріалу. Сучасна цивілізація входить в епоху особливого типу прогресу, що характеризується складними й суперечливими процесами, які відбуваються в Україні останнім часом. Вони детермінують пошук нової стратегії розвитку системи освіти, зумовлюючи суттєві трансформаційні та повномасштабні зміни іiі пріоритетів і цінностей.

Освіта як один із базисних конструктів цивілізації в умовах сьогодення має стати визначальним чинником соціально-економічного поступу суспільства, розвитку духовної культури людства, відтворення іï інтелектуального потенціалу. Це, своєю чергою, стосується дошкілля як початкової ланки всієї освітньої системи, а ступінь дошкільного дитинства розглядається як один із головних освітніх резервів.

Зазначимо, що пріоритетом освіти є особистість дитини, а створення комфортних умов для формування її неповторної унікальності, розвитку здібностей та обдарувань сприятиме успіхам дитини в майбутньому.

3 гуманістичних позицій дошкільне дитинство розглядається як самоцінний етап життя людини; етап підготовки до наступного періоду життя шкільного дитинства; період, протягом якого формуються не тільки передумови, а й провідні риси особистості, що визначатимуть іiі спрямованість, поведінку й діяльність протягом усього життя [7].

Плідні філософсько-педагогічні ідеї щодо розвитку дитиноцентризму як «серцевинної ідеї змін в освіті й суспільстві» містять дослідження В. Кременя [6]. Так, філософ звертає увагу на той факт, що «наше доросле суспільство зможе бути ефективним, гуманним i демократичним, якщо ми затвердимо людиноцентризм у суспільному житті як створення умов для плідної діяльності кожної людини в ньому», зауважуючи при цьому, що «дитиноцентризм в освіті - це не проголошення гасла «Все краще - дітям», і це не любов до дітей узагалі як таких. Це - виокремлення у кожній дитині їі сутнісних особистісних рис і максимально можливе наближення навчання і виховання цієї дитини до іiі конкретних здібностей. Ідея дитиноцентризму має проходити червоною ниткою в усіх змінах реформації й модернізації системи освіти» [6, с. 17].

Перш ніж з'ясувати, у чому полягають підходи науковців до вивчення проблеми розвитку професіоналізму особистості вихователя дошкільного навчального закладу, важливо, на нашу думку, усвідомити й проаналізувати надбання педагогічної та психологічної теорії щодо становлення й розвитку дошкільної освіти.

Варто наголосити на тому, що педагогічна професія - одна 3 найстаріших і найпочесніших в історії людства. Щодо професії вихователя ДНЗ, то вона виникла ще в XVII-XVIII ст. 3 появою перших дитячих садків. В Україні кадри для галузі дошкільної освіти почали готувати 3 1907-1908 pр. Фребелівським жіночим педагогічним інститутом.

На основі аналізу науково-педагогічної літератури $з$ проблеми дослідження можна стверджувати, що Т. Богуславською [2] виокремлено певну періодизацію зазначеного вище процесу. Так, на основі критеріальної матриці визначено такі етапи:

- загальнотеоретичний (до середини 80-х рр. XX ст.) - відбувалося формування теоретичної основи дошкільної освіти, а також програмно-методичне оформлення його змісту;

- парадигмальний (1986-1991рр.) - запропоновано базові концепції дошкільної освіти, що визначили принципово нові підходи до їі змісту;

- концептуальний (1992-1999 рр.) - розроблено та представлено варіативні психолого-педагогічні концепції дошкільної освіти. 
Охарактеризуємо докладно виділені етапи.

1. Базові теорії Л. Виготського й О. Леонтьєва стали методологічною основою для розроблення загальних теорій психології дошкільної освіти, які створені в 1950-1970-ті рр. видатними психологами О. Запорожцем і Д. Ельконіним.

2. Охарактеризовані теоретичні підходи стали гносеологічною основою для психолого-педагогічних концепцій дошкільної освіти, які продуковані в радянській педагогіці та психології другої половини 80-х - першої половини 90-х рр. ХХ ст. Цілісне вивчення процесу розвитку теорії змісту дошкільної освіти і 1986-1991рр. дає можливість стверджувати, що цей етап мав парадигмальний характер.

3. Розгляд концептуального етапу розвитку теорії дошкільної освіти (1992-1999 рр.) засвідчив, що в цей період визначилася тенденція переходу до творчого й більш індивідуалізованого процесу дошкільної освіти. Усе це сприяло загалом піднесенню системи дошкільної освіти на більш високий і якісний рівень.

Дошкільна освіта тоталітарного суспільства впродовж усього часу свого існування відзначалася всіма тими ознаками, що притаманні освіті зокрема й усьому суспільству. Характерними iii особливостями були такі, як налаштованість передусім на озброєння дітей знаннями, уміннями та навичками; забезпечення функціональної придатності вихованців до життя насамперед у стабільних економічних умовах; відведення домінуючої ролі в організації навчального процесу контролюючим інстанціям; ставлення до вихователя дітей як до постачальника знань, проголошувача істин, контролера. Пріоритетними якостями у вихованні визнавалися слухняність дітей, добра виконавська дисципліна й уміння діяти чітко за вказівками дорослого, старанність, обізнаність, добра навченість.

На думку вчених, роль дошкільного дитинства полягає в оволодінні загальним людським досвідом, у формуванні психічних якостей, які необхідні для життя. Зазначимо, що дошкільне дитинство забезпечує загальний розвиток, який слугує фундаментом для набуття спеціальних знань і навичок 3 різних видів діяльності. Усі новоутворення дошкільного віку $\epsilon$ не сумою знань, а певним рівнем пізнавальної активності, самостійності, творчості, ставлення до себе й до інших. Сформовані в цей період якості визначають загальний характер поведінки дитини, їі ставлення до світу, значною мірою є основою їі життєдіяльності в майбутньому [5].

Отже, аналіз першоджерел свідчить, що саме вихователь має якнайтонше розуміти й відчувати дитячий крихкий внутрішній світ - «пізнання розумом і серцем». Такі цільові орієнтири зумов- люють нові вимоги до особистості вихователя дошкільного навчального закладу.

Предметом педагогічної діяльності В. Давидов i В. Петровський у Концепції дошкільного виховання називають організацію освітньо-виховної діяльності дітей, спрямованої на освоєння ними соціокультурного досвіду за умови розвитку особистості дитини [3]. Сучасні концепції дошкільного виховання, авторські педагогічні технології (М. Монтесорі, С. Русова, В. Сухомлинський та інші) передбачають для виконання головної мети педагогічної діяльності створення в саду умов, що забезпечуватимуть дітям їх усебічний розвиток. Формулюючи мету педагогічної діяльності дошкільного навчального закладу, а отже, і мету діяльності вихователя цього закладу, сучасні дослідники вказують на те, що основні цілі виховання та навчання дітей у дитячому садку пов'язуються з розвитком особистості дитини, формуванням розумової активності, творчих здібностей і моральної відповідальності.

Сучасний дошкільний навчальний заклад гостро потребує вихователя, здатного адекватно та швидко реагувати на зміни освітньої ситуації, використовувати інноваційні технології виховання, спроможного до принципової їх переорієнтації на сучасні пріоритети, до творчого розв'язання нових назрілих проблем, у зв'язку з чим мета освіти може бути представлена як безперервний особистісно-професійний розвиток педагога якісно нового типу. Зупинимося детальніше на його характеристиках:

- висока громадянська відповідальність і соціальна активність;

- поєднання любові до вихованців із професійними знаннями й захопленістю педагогічною справою;

- потреба в постійній самоосвіті, саморозвитку й життєвому самоздійсненні;

- володіння методологічною культурою мислення, що визначає готовність вихователя до аналізу, узагальнення й перетворення педагогічних ситуацій, до прийняття рішень про вибір, застосування і створення засобів педагогічного впливу;

- підвищення рівня методичної компетентності й удосконалення організаційно-змістових основ викладання;

- високий рівень професіоналізму, педагогічної майстерності, нарешті, звеличення особистості вихователя.

Вимоги до професійної діяльності вихователя $\epsilon$ імперативною системою професійних якостей, які й визначають успішність його педагогічної діяльності. 3 вищезазначеного зрозумілим $є$ той факт, що професіоналізм педагога дошкільного навчального закладу полягає в спрямованості його зусиль на створення умов для гармонійного розвитку 
вихованців, володіння інноваційними методами i прийомами роботи 3 дітьми за конкретними методиками, створення атмосфери співробітництва й співтворчості, установлення та регулювання взаємин із дітьми, батьками, колегами тощо.

Так, у державних документах, зокрема Білій книзі української освіти (2009р.), наголошується на тому, що стратегічною метою системи фахового зростання педагогічних працівників є забезпечення умов для їхнього безперервного професійного розвитку й саморозвитку, формування відповідних потреб [1].

Для успішної реалізації цих завдань вагомого значення набуває розуміння вихователем того, як саме дійти до вершин творчого саморозвитку, акмеологічної компетентності, самопроектування успішної кар'єри.

Своєрідним орієнтиром у дослідженні цієї проблеми, предметом спеціального аналізу є теза К. Ушинського, який слушно зауважував: «Лише особистість може впливати на розвиток і визначення особистості, лише характером можна створювати характер» [8, с. 191].
Висновки та перспективи дослідження. Можемо зазначити, що в умовах сьогодення відбувається переорієнтація особистості педагога на нові результати: висуваються якісно інші вимоги до рівня професіоналізму вихователя закладу дошкільної освіти.

Сучасний заклад дошкільної освіти гостро потребує вихователя, здатного адекватно та швидко реагувати на зміни освітньої ситуації, використовувати інноваційні технології виховання, спроможного до принципової їх переорієнтації на сучасні пріоритети, до творчого розв'язання нових назрілих проблем, у зв'язку з чим мета освіти може бути представлена як безперервний особистісно-професійний розвиток педагога якісно нового типу.

Наукою доведено, що закономірності творення нової особистості в умовах сьогодення як ніколи актуалізують проблему розвитку професіоналізму фахівця в сучасній теорії та практиці навчання й виховання, а формування й удосконалення компонентів досліджуваного феномена можливі тільки в процесі саморозвитку особистості.

\section{Література}

1. Біла книга національної освіти України / НАПН України ; за заг. ред. В.Г. Кременя. Київ : Інформ. системи, 2010. 340 с.

2. Богуславская Т.Н. Формирование теории содержания дошкольного образования в отечественной педагогике второй половины ХХ в. Педагогика. 2013. № 2. С. 31-38.

3. Давыдов В.В. Проблемы развивающего обучения. Москва, 1986. 234 с.

4. Зязюн І.А. Філософія поступу і прогнозу освітньої системи. Педагогічна майстерність: проблеми, пошуки, перспективи : монографія. Київ, Глухів : РВВ ГДПУ, 2005. С. 10-18.

5. Козлова С.А., Куликова Т.А. Дошкольная педагогика. Москва : Академия, 2000. 415 с.

6. Кремень В. Освіта в контексті сучасних соціокультурних змін. Філософія освіти. 2008. № 1-2(7). C. $15-21$.

7. Професійна освіта : словник : навчальний посібник / уклад. С.У. Гончаренко та ін. ; ред. Н.Г. Ничкало. Київ : Вища школа, 2000. 380 с.

8. Ушинский К.Д. Три элемента школы. Педагогические сочинения. Москва : Педагогика, 1988. Т. 1. С. 177-193.

\section{References}

1. Kremen V. H. (2010) Bila knyha natsionalnoyi osvity Ukrayiny [White Paper on National Education of Ukraine]. Kyiv : Inform. systems [in Ukrainian].

2. Boguslavskaya T. N. (2013) Formirovanie teorii soderzhaniya doshkolnogo obrazovaniya v otechestvennoy pedagogike vtoroy polovinyi XX veke [Formation of the theory of the maintenance of preschool education in domestic pedagogy of the second half of the XX century]. Pedagogy. Vol. 2. P. 31-38.

3. Davydov V. V. (1986) Problemyi razvivayuschego obucheniya [Problems of developmental learning]. Moskva [in Russian].

4. Zyazyun I. A. (2005) Filosofiia postupu i prohnozu osvitnoi systemy.Pedahohichna maisternist: problemy, poshuky, perspektyvy [Philosophy of progress and forecast of the educational system. Pedagogical skill: problems, searches, prospects]. Glukhiv: RVV GDPU [in Ukrainian].

5. Kozlova S. A. (2000) Doshkolnaya pedagogika [Preschool pedagogy]. Moskva : Akademiya [in Russian].

6. Kremen V. (2008) Osvita v konteksti suchasnykh sotsiokulturnykh zmin [Education in the context of modern socio-cultural changes]. Philosophy of education. Vol. 1-2 (7). P. 15-21.

7. Goncharenko S. U. (2000) Profesiina osvita: slovnyk [Vocational education: dictionary]. Kyiv: High School [in Ukrainian].

8. Ushinsky K. D. (1988) Tri elementa shkolyi. Pedagogicheskie sochineniya [Three elements of school. Pedagogical works]. Moskva : Pedagogy [in Russian]. 